BACKGROUND TO SHAKESPEARE 
Macmillan International College Editions (MICE) will bring to university, college, school and professional students, authoritative paperback books covering the history and cultures of the developing world, and the special aspects of its scientific, medical, technical, social and economic development. The MICE programme contains many distinguished series in a wide range of disciplines, some titles being regionally biassed, others being more international. Library editions will usually be published simultaneously with the paperback editions. For full details of this list, please contact the publishers.

Other titles of interest

General Editor Professor A. N. Jeffares

Commonwealth Writers Series

Robson: Ngugi wa Thiong'o

Carroll: Chinua Achebe

Kiernan: Patrick White

Gurr and Hanson: Katherine Mansfield

New Literature Handbooks

King: West Indian Literature

King: The New English Literatures - cultural nationalism in a changing world

Rutherford and Hannah: Commonwealth Short Stories

Burton and Chacksfield: African Poetry in English

Larson: The Emergence of African Fiction 


\section{BACKGROUND TO SHAKESPEARE}

M. M. Badawi

Fellow of St Antony's College,

Oxford

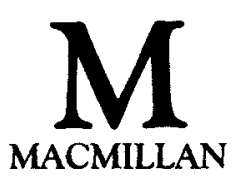


(C) M. M. Badawi 1981

Softcover reprint of the hardcover 1st edition 1981

All rights reserved. No reproduction, copy or transmission of this publication may be made without written permission.

No paragraph of this publication may be reproduced, copied or transmitted save with written permission or in accordance with the provisions of the Copyright Act 1956 (as amended).

Any person who does any unauthorised act in relation to this publication may be liable to criminal prosecution and civil claims for damages.

First published 1981

Reprinted 1986

Published by MACMILLAN EDUCATION LTD

Houndmills, Basingstoke, Hampshire RG21 2XS

and London

Companies and representatives

throughout the world

ISBN 978-0-333-30535-5 ISBN 978-1-349-16636-7 (EBook)

DOI 10.1007/978-1-349-16636-7 


\section{Contents}

Preface vii

1 The Study of Shakespeare 1

2 Shakespeare the Man (1564-1616) 16

3 The Social Background of the Plays 25

4 Cosmology and Religion $\quad 46$

5 The Classical Background $\quad 69$

6 Elizabethan Stage Conditions 96

7 The Chronology and Sources of the Plays 117

Appendix: A Note on the Histories $\quad 126$

Index 137 
FOR MIEKE 


\section{Preface}

This book is designed primarily for the overseas student of Shakespeare, especially for the Afro-Asian student with no classical and little or no Christian background. That is why it attempts to take very little for granted. The assumptions which lie behind the works of Shakespeare, and for that matter behind the whole body of Western literature, and that are tacitly accepted by the Engl ish and the European reader are here explicitly stated in order to provide the reader with the frame of reference necessary for the understanding and appreciation of Shakespeare's plays. Similarly, the language of exposition is deliberately made straightforward and complex issues are presented in a manner which may at times border on simplification. However, I have endeavoured not to lose sight of my specific reader, and if by the end of the book he feels that he has been helped in understanding Shakespearean drama or that at least some obstacles have been removed from his path, my labour will not have been in vain. In short, I have tried to write the kind of book which I wished I had read on my first introduction to English literature.

It is hoped that, beside being a useful introduction when it is read straight through from beginning to end, the book may prove to be of some value to the student as a work of reference. With this latter end in mind I have provided a comprehensive index.

Finally, I should like to express my gratitude to my friend Professor Mahmoud Manzalaoui, of the University of British Columbia, who kindly read the first draft of this book and made many valuable suggestions. 


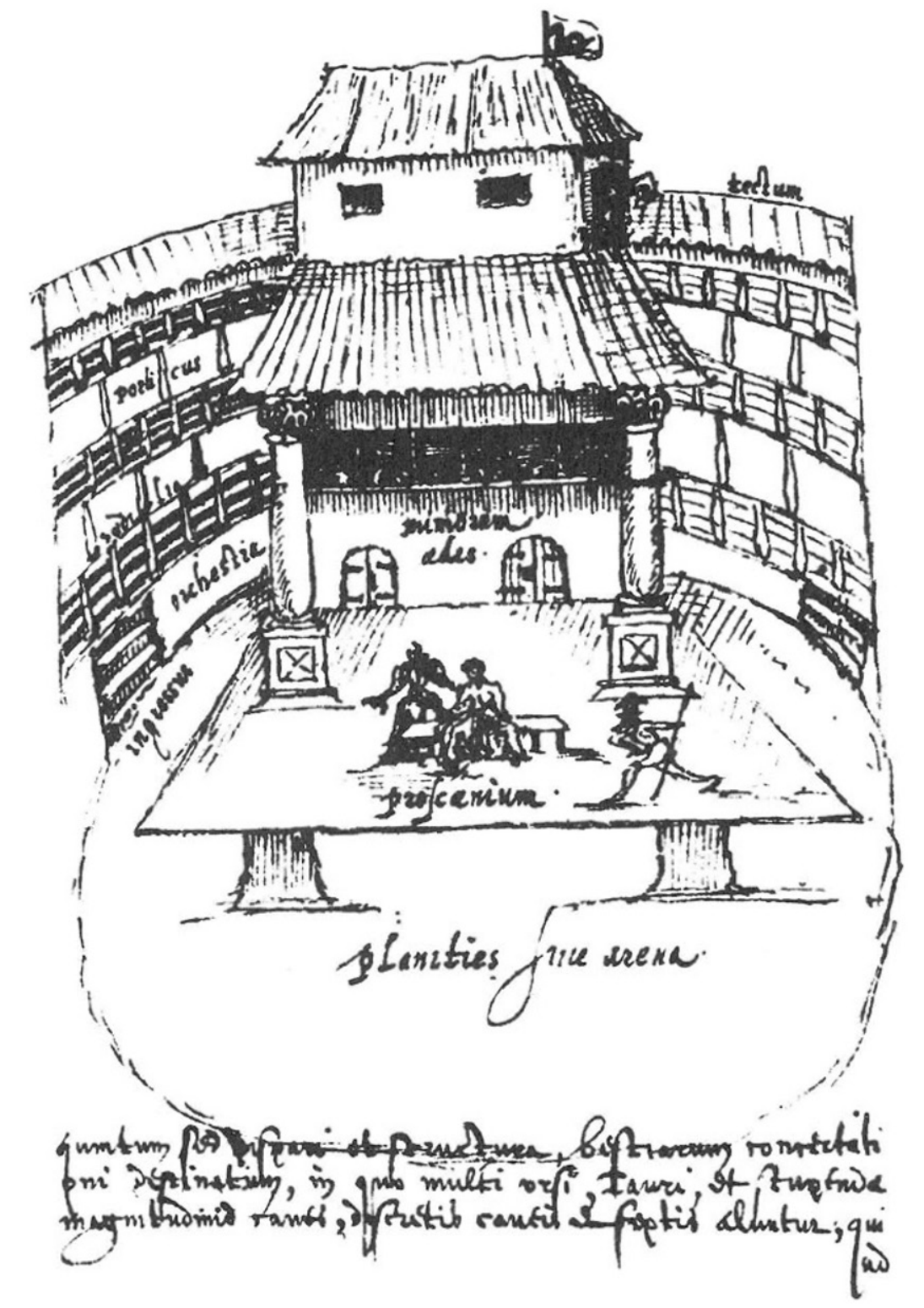

The Swan Theatre: a sketch made in $\mathbf{1 5 9 6 .}$ 